\title{
Volume 152: Editorial
}

2013 has been a mixed year for the Journal of Agricultural Science. We have seen a significant increase in the number of papers submitted but a fall in the journal Impact Factor. The number of submitted papers has risen once again and we passed the 600 mark in mid-December (488 papers submitted at the same time last year). This is by far the highest number of papers that we have ever had submitted to the journal. However after some confusion when the Impact Factor results were released in June the disappointing news is that our Impact Factor has fallen from 2.041 in 2012 to 1.691 in 2013.

2014 will see the publication of a Special Issue containing several papers that were presented at the $17^{\text {th }}$ International Nitrogen Workshop, held at Teagasc in Dublin in June 2012.

Julie Lauren and Bob Hunter relinquished their positions on the Editorial Board at the end of 2013 and so we thank them both for their excellent contribution to the journal over the years and wish them well for the future.

A number of new members have been appointed to the Editorial Board to accommodate the increasing volume of submitted papers and will be taking up their positions in 2014:

Paul Williams, Queens' University Belfast Ragab Ragab, Centre for Ecology \& Hydrology
Shiwei Guo, Nanjing Agricultural University YuanYuan Song, South China Agricultural University Owen Fenton, Teagasc, Ireland Ed Charmley, CSIRO

May we take this opportunity to welcome our new members to the Editorial Board.

As always, we are indebted to our Editorial Board members and the many international reviewers who assist the Board by conducting detailed peer reviews. Without these willing volunteers, our task would be impossible and the continued success of the journal owes a lot to them. A list of those who have assisted by reviewing papers for us in 2013 can be found on the Journal's website at http://journals.cambridge.org/action/displayjournal? jid=AGS.

We look forward to a successful year in 2014 where we can continue to build upon the reputation that Journal of Agricultural Science, Cambridge has achieved over the last 108 years.

Paul Bilsborrow - Senior Crops \& Soils Editor Julian Wiseman - Senior Animals Editor Alison Sage - Editorial Assistant 